Institute of $\mathbf{F}_{\text {ood and }} \mathbf{A}_{\text {gricultural }} \mathbf{S}_{\text {ciences }}$

\title{
Housing As We Grow Older: Moving to Smaller, More Efficient Housing ${ }^{1}$
}

Virginia Peart and Carolyn Wilken²

It is essential as we grow older to recognize that our present home may not serve us as well as it once did. Our new plan must include the total living environment, our personal and social requirements and the services we might need as we grow older. The place we choose to live can enrich our lives and help maintain our independence and self-direction.

A move to smaller, more efficient housing gives you an opportunity to reduce household and outdoor chores, thereby providing time to renew acquaintances, make new friends, and find the safety, security, and the services you need.

The time you spend in developing your plan can bring satisfaction to you, your family, and friends. As you prepare to leave your present home, get help in selling your house or making the proper arrangements with your landlord. Take the time to sort your possessions, decide how the move will be made, and make the plans for settling into your new home.

This publication will help you think through the decisions to be made and help you develop your plan for choosing and settling in your new home.

\section{Think About the Way You Want/Need to Live}

As you prepare for the move, consider your needs, interests, and abilities, as well as limitations. Review the needs and activities that are necessary, and those that are for enjoyment. Think about how much time you will spend in your new home, the immediate surroundings, and the neighborhood -visiting with family and friends, participating in community activities, shopping for goods and services, and doing volunteer work.

1. This document is Fact Sheet FCS 3190, a series of the Department of Family, Youth and Community Sciences, Florida Cooperative Extension Service, Institute of Food and Agricultural Sciences, University of Florida. Publication date: November 2002. First published: January 1994. Revised: Novembe 2002. Originally published as SAH-5. Adapted for use in Florida from "Housing as We Grow Older," prepared by Marian Feeney, Housing/Energy Education Specialist, Rhode Island Cooperative Extension Service. Please visit the EDIS web site at http://edis.ifas.ufl.edu

2. Adapted by Virginia Peart, former associate professor, Housing; revised by Carolyn Wilken, associate professor, Family Life; and reviewed by Nayda I. Torres, professor, Family and Consumer Economics, Department of Family, Youth and Community Sciences, Cooperative Extension Service, Institute of Food and Agricultural Sciences, University of Florida, Gainesville, 32611. 


\section{Sort Out Your Possessions}

It's amazing what can be accumulated over a lifetime. Closets are filled, dresser drawers bulge, cupboards have little room left, and boxes of "stuff" multiply in the garage. For easier, safer living, start to reverse that accumulation process.

\section{Donate or Give Away}

- Give an early inheritance. A prized possession you no longer use (silver, china, crystal, linens) could be treasured now by a younger relative.

- Donate clothing, appliances, furniture and household goods to a charitable organization. Remember that the value of goods donated counts as a charitable contribution for income tax purposes.

- Check with the Historical Society to see if they would welcome your old photos, period costumes, and household items.

\section{Sell}

- Hold a garage sale or join friends and neighbors in a combined sale. Items not sold can be donated.

- Consider a consignment store for good quality women's clothing. They will pay you about $40 \%$ of their selling price.

\section{Discard}

- Throw away outdated medicines, cosmetics and perfumes, broken appliances, old magazines, and food that has been on the shelf too long.

\section{Store}

- Pack away items that are seldom used but are worth keeping. Use sturdy cartons, seal them, and label the contents on the front as well as the top of the box. These can then be stacked in an out of the way place.

If you are considering new furnishings or appliances, when you move, consider these suggestions.

- Ask family and friends about unused furnishings.

- Offer a trade.

- Make purchases from tag sales, rummage sales, second-hand or retail stores.

- Determine the actual cost of furnishings purchased on credit and read the contract carefully before you buy.

Before moving you may also want to: replace box springs and mattresses that are over ten years old; paint, refinish or restyle furniture; and re-upholster or slipcover furniture with sturdy, soil-resistant fabric.

Visit your new home or a model of it and think of the ways to arrange your furnishings. Ask for a floor plan to scale or make one yourself ( $1 / 2$ inch equals 1 foot). Indicate the ways doors open and how much space they take. Note locations and sizes of heating units and windows. Note the locations of electrical outlets, light switches, and call bells. 
The time spent in planning saves confusion when you move and prevents taking items that won't fit into your new home. Your tape measure, yardstick, and pencil will be invaluable at this stage.

Develop a plan for each room. Here is an example of what one person might plan for a smaller living room. Repeat the chart for your new bedroom and any other spaces you will have.

\begin{tabular}{ll} 
Room: & Living Room \\
\hline Activities: & $\begin{array}{l}\text { Reading, TV, Visiting, } \\
\text { Hobbies }\end{array}$ \\
\hline $\begin{array}{l}\text { Furnishings } \\
\text { Needed: }\end{array}$ & $\begin{array}{l}\text { Sofa, 2-soft side chairs, } \\
\text { end table, table lamp, } \\
\text { floor lamp, TV and TV } \\
\text { stand }\end{array}$ \\
\hline Take from Home: & $\begin{array}{l}\text { Side chairs, end table, } \\
\text { table lamp, floor lamp, }\end{array}$ \\
\hline TV \\
$\begin{array}{l}\text { Need to Buy or } \\
\text { Trade Furniture } \\
\text { for: }\end{array}$ & Sofa, TV stand \\
\hline
\end{tabular}

\section{Learn About Your New Home}

Many things may be different in your new home. If you move to a unit within a multiple housing complex, or a senior citizens' community, there may be tenant orientation programs or a resident handbook to help smooth the way. If not, ask the building or community manager any questions you may have.

\section{Services}

If you move to a multiple-dwelling unit, you will want to know about essential services. Where are the tenant and service elevators located? How do you operate the elevators? Where are the emergency exits and what are the emergency exit procedures?

What are the regulations for a personal car, visitors' cars, and parking? Does the management provide a courtesy car, minibus, or tenant transportation service? What are the emergency transportation provisions and what public transportation systems are nearby?

Is there a mailbox inside the building or within walking distance? When is the mail delivered? What are the regulations on mailboxes and package delivery?

What are the regulations regarding a personal $\mathrm{TV}$, and the procedures and cost for a master antenna or cable hook-up?

What are the procedures for trash collection? When is it collected? How should it be packaged and sorted?

Can arrangements be made for newspaper delivery to an individual unit or a central location? What are the payment procedures?

What maintenance and cleaning procedures are the responsibility of the management or the tenant? Are there restrictions regarding window treatments, wall hangings, carpet and appliance installations? What are the procedures for obtaining the services of the management?

\section{Safety}

What are the procedures and regulations for interior and exterior door security? What are the procedures for tenants and guests entering the building? 
Where are the call bells located? What are the response procedures?

Where is the fire extinguisher located? How is it used? Who should use it?

Is the lighting adequate for easy access to building entrances and exits, hallways and community rooms?

\section{Agreement}

Read the contract or lease agreement carefully. If you need help or have questions about any items, ask the unit manager, a family member, a friend or a lawyer. Are the tenant's costs itemized by the month? Are there occasional or seasonal expenses such as window washing, blind cleaning, painting, or carpet cleaning?

\section{The Community}

What services are located in the community, such as medical and health care, recreation, laundry/dry cleaning, convenience food store, and banking? Where are they located? What are the business hours? Do you need an appointment?

What kind of services are located in the neighborhood: drug store, post office, clothing store, grocery store, bank, health care? Where are they located? What are their hours? How will you get there? Do they deliver? What is the delivery cost? Do they offer credit?

\section{Getting Ready for the Move}

Moving brings mixed feelings -excitement about your new home and either sadness or delight at leaving the old home and neighborhood. Regardless of how you feel, a well-thought-out plan makes this hectic time easier. First, decide whether friends, relatives, or a professional mover will move you and whether to do your own packing or have the movers pack. Do consider the time, energy, and cost involved in moving.

\section{Do-It-Yourself-Move}

- Pack with the help of friends and relatives. Allow enough time for sorting, packing and labeling.

- Check household insurance regarding moving.

- Check two or three truck rental companies for cost, location and other regulations.

- Rent protection pads to cushion furniture and prevent scratching and marking, if not provided with the truck.

\section{Professional Movers}

- Allow several weeks for arrangements.

- Get two or three cost estimates in writing.

- Decide who will pack: the movers or you, family, and/or friends.

- Check household insurance regarding moving.

- Learn about moving regulations, for example, will the movers' insurance cover items you pack?

- Read "Summary of Information for Shippers of Household Goods" provided by movers. 
- Be aware that small moving loads are often packed in a large van with other peoples' belongings in long distance moving. This can lead to uncertain delivery schedules.

\section{Hints to Make Moving Easier}

- Send rugs, draperies, and clothes to the cleaners before moving and have them delivered to your new address before movers arrive.

- Collect plastic bags, boxes and crates for packing. Heavy cartons may be rented and/or purchased from the truck rental or moving company.

- Use cartons with dividers for glasses and other breakables.

- Use clean towels, pillowcases and sheets to wrap dishes.

- Stand up wrapped plates in cartons -plates standing on end travel better.

- Pack snugly, but do not force articles into a container.

- Write the contents on each box and which room it will go to.

- Make hand holes in cartons to make them easier to lift.

- Keep each box light enough to lift easily.

- Do not move flammable or potentially hazardous substances.
- Put important papers where you can find them easily. Do not send them in the moving truck.

- Use up frozen and refrigerated food before moving. Keep a carton for last minute food and utensils. Pack them after the last meal so they will be ready for the first meal at the new address. Include a manual can opener. You may have to rely on canned foods for these meals.

- Use several roll-ups of clothes. To make a roll-up, place a sturdy blanket or bedspread on the bed. Remove clothes from closet on hangers. Lay clothes on blanket in a neat pile. Fold blanket over clothes from both sides. Two people can carry this easily. Reverse the procedure at destination, and hang clothes in the new closet.

- Leave clothes and items that won't break in drawers. Then each drawer may be carried separately if the entire piece is too heavy.

- Plan to arrive at your new home before the movers. Have your furniture layout handy to tell the movers where to place each item.

\section{Establishing Your New Home}

As you arrange your furnishings and organize your belongings in your new home, remember to conserve your human energy and consider space allocation, comfort and safety. 


\section{Space Allocation}

- Arrange large pieces of furniture around the room, parallel to walls.

- Make small rooms seem more spacious by using light, soft, related colors for the background -- floors, walls, and window treatments -- and add small bright touches of color in accessories.

- Store items where they are first used, easy to reach and easy to use.

- Organize collections such as snapshots, photographs, spoons and plates. They can be arranged in frames or on boards and hung on the wall, or on folding screens or on shelves to save space.

\section{Comfort Factors}

- Place sitting furniture away from heat sources and drafts.

- Keep the height of furnishings in mind. Do not block windows or heat sources.

- $\quad$ Place bed(s) away from drafts, with a clear passageway to the bathroom, closet and storage.

- Arrange seating in groups for comfortable conversations. Remember that many reclining chairs require six feet of space.

- Satisfy your love of gardening by arranging plants around a sunny window, on shelves, or hang them from the ceiling, window casing or on a tension pole.

\section{Safety Suggestions}

- Provide two or three feet for traffic paths around the bed, between table and wall, and in front of storage areas for easy access.

- Plan for a telephone near the bed or beside a comfortable chair which provides privacy, easy access and safety.

- Place TV opposite your favorite chair or sofa, eight to twelve feet away to create picture depth and prevent eye strain.

- Plan good lighting at a table; in the kitchen; by a chair for reading and doing close work; and other places as needed for reading labels on medicines and household products. Lighting should give enough light for comfort and safety. The shade should have a white lining to throw the light where you want it, and the bottom of the shade should be level with your eyes when seated so you will not see the light bulb or bright light inside the shade.

- Plan for night lights and safety lights in the bathroom and hallway, on switchplates and call bells.

\section{Conserve Human Energy}

- As you settle into your new home, do only as much as you feel you can do in one day.

- Avoid reaching, standing on a chair or stool and using a step ladder. If necessary, ask for help. 
- Take your time, avoid bumps and bruises.

- Ask phone callers to allow several rings so that you can answer without hurrying.

- Keep these telephone numbers by the phone: superintendent or manager, police, doctor, fire department, drug store, closest friend, closest relative, and others most frequently used.

\section{Change of Address}

Call or write the following, if applicable, to ask that services be discontinued on moving day and to start services at your new address: gas company, electric company, telephone company, water company, fuel company (gas/oil), trash collector, and newspaper office or paperboy. Make a list for easy checking of final services and new service dates and times.

Pick up a "Change of Address Kit" from the Post Office. The kit includes a card for notifying your present postmaster and several "change of address cards" for friends, relatives, businesses, publishers, and others. Leave one with your present landlord or the realtor. Extra cards may be picked up at the Post Office. "Stick-on" name and address labels save time and energy when filling out the cards.

Check the change of address suggestions that are appropriate: Social Security Office, social services, Medicaid and Medicare, doctor(s), dentist, lawyer, Board of Elections, Motor Vehicle Department, insurance companies, bank(s), creditors, magazine subscriptions, book and record clubs, church and fraternal organizations, friends and relatives.

\section{Adjusting to Your New Environment}

Making new friends will be important. Your next door neighbor may be shy, so introduce yourself. When participating in social activities, be gracious and friendly. Be a good listener as well as a good participant.

The first person you meet may not become a close friend. People are different, with separate interests, but a friendship with someone with similar interests will develop -be patient.

Invite others to join you in getting to know each other. Start a buddy system. Share talents and skills. Maybe go shopping together. Invite others in to play cards, or for a snack, or just to visit. Accompany a friend to the doctor.

Invite neighbors who rarely go out to accompany you. If they turn you down the first time, do not give up. Ask again. They may need a little encouragement. Most important, find someone you can enjoy spending time with.

Find out about the activities and services in your neighborhood. The more you know about the community, the more you can enjoy the advantages it offers and the sooner you will feel safe and secure in your new environment. 